\title{
Comparative History of Communication Studies: France and Germany
}

\author{
Stefanie Averbeck*
}

University of Leipzig, Institut for Communication and Media Studies

\begin{abstract}
The aim is to outline general differences in two academic cultures, considering historic perspectives: German 'Kommunikationswissenschaft' with its roots in 'Publizistik-' and 'Zeitungswissenschaft' and French 'Sciences de l'information et de la communication' with its roots in semiotics and cultural views on communication. There are different internal and external (societal and political) means which influenced the development of communication studies and theories in each of the two countries.

The Sciences de l'information et de la communication (SIC) gained their academic acceptance in France in 1975 which under international comparison was late. One strong external moment of the instutionalization of SIC was the political aim to modernize the French University for the so called 'information society'. The French researchers developed their own focus. Semio-pragmatics and social constructivism are two basic theoretical orientations which, after the end of the limiting structuralistic paradigm of the $1960^{\text {ths }}$, lead to a fruitful connection of the analysis of the micro and the meso-level of communication processes. Thus, Pragmatics and Symbolic Interactionism played an important role in French SIC much earlier than in Germany.
\end{abstract}

Keywords: History of communication studies, French Sciences de l'information et de la communication, German Kommunikationswissenschaft, communication theories, social constructivism.

\section{INTRODUCTION}

The aim of this paper ${ }^{1}$ is to outline general differences of two academic cultures, considering historic perspectives: German 'Kommunikationswissenschaft' with its roots in 'Publizistik-' and 'Zeitungswissenschaft' and French 'Sciences de l'information et de la communication' with its roots in semiotics and cultural views on communication. ${ }^{2}$ The $S c i$ ences de l'information et de la communication (SIC) gained their academic acceptance in France in 1975 which under international comparison was late. While rethinking the status of communication studies since Paul F. Lazarsfeld, the French researchers developed their own focus (see also Puustinen, 2007). Semio-pragmatics and social constructivism are two basic theoretical orientations which, after the end of the limiting structuralistic paradigm of the 1960s, lead to a fruitful connection of the analysis of the micro and the mesolevel of communication processes. Thus, Pragmatics and Symbolic Interactionism played an important part in French SIC much earlier than in Germany (Averbeck, 2005).

"Address correspondence to this author at the University of Leipzig, Institut for Communication and Media Studies, Tel: 0049-341-9735715; Fax: 0049341-9735709; E-mail: averbeck@rz.uni-leipzig.de

\footnotetext{
${ }^{1}$ This paper is an extended version of a presentation on the occasion of the IAMCR-conference in Paris 23 July 2007.

${ }^{2}$ In the case of France the article presents findings of my habilitation project on the epistemological discourse of French Sciences de l'information et de la communication 1975-2005 and in the case of Germany of my PhDdissertation on Newspaper Science in the $20^{\text {th }}$ century in Germany and also my workings with Arnulf Kutsch on the history of communication studies in Germany. For this article it was impossible to outline details and single approaches (for example of Charaudeau, de Certeau, Escarpit, A. Mattelart, Morin, Mucchielli, Odin, Quéré or Véron which are widely considered in my habilitation project (in addition to my present article see Averbeck 2000, 2005).
}

Communication studies in Germany are a comparatively 'old' discipline, which emerged since 1916 from newspaper studies. But the Nazi past of German 'Zeitungswissenschaft' caused a rejection of self-reflect over nearly three decades (Hardt, 2002; Kutsch, 2006; Koenen, 2007a). Today, the social history of the discipline, as well as its history of ideas, is a field of intense research in Germany. Meanwhile, French researchers are just about to start writing the history of communication studies in their own country (Balle \& Cappe de Vaillon, 1983; Béaud \& Kaufmann, 1998; Boure, 1997; Boure, 2002; Boure, 2005; Cazeneuve, 1982; Marhuenda, 1983; Mattelart, 1983; Mattelart \& Mattelart, 2002; Georgakakis \& Utard, 2001; Jeanneret \& Ollivier, 2004; Olivesi, 2006). But the body of knowledge has been reflected from the start of the SIC until now. The French researchers have no urgent need to look at their academic past, especially not from a moral point of view, like the Germans. This may be the reason why in France the path has always been open for rich epistemological debates. These debates focused early on epistemology and that might also be the reason why the concept of communication is different to that used in Germany. Another reason is that German communication studies are rooted in 'Zeitungswissenschaft', in journalism studies and in mass communication research. Consequently, they are predominantly dealing with public, mass media mediated communication (Averbeck, 1999; Averbeck \& Kutsch, 2002; Hachmeister, 1984; Löblich, 2007; Roegele \& vom Bruch, 1986; Koivistu \& Thomas, 2007). French scholars in return, have an extensive concept of social or human communication. This concept is fundamentally based on the philosophy of language, as well as on semiological and anthropological premises, promoting the fusion of semiotics and pragmatics (Averbeck, 2000; 2005).

The different history of the social corpus, as well as the different history of ideas of French and German communica- 
Table 1. Conceptualization: the History of Communication Studies

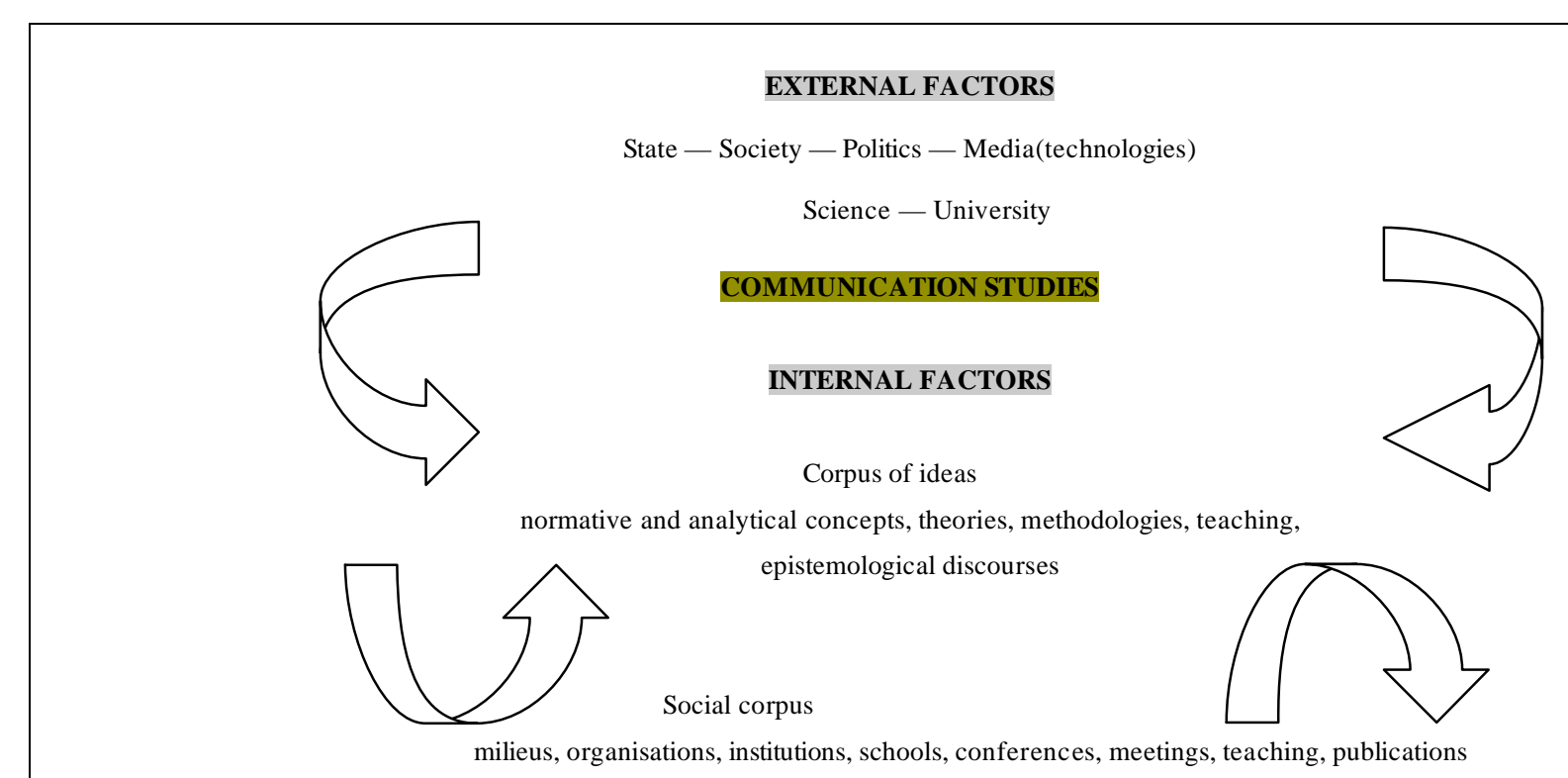

following Averbeck \& Kutsch, 2002

tion studies, led to a striking differentiation of communication concepts; reduced to one denominator: 'public communication' in Germany, 'social communication' in France (Averbeck, 2005). Or, using the terminology of 'flow' and 'meaning' introduced by Elihu Katz (1987, p. 39) for classifying approaches in communication studies: 'meaning' in France and 'flow' in Germany. ${ }^{3}$ Also, Alex Muchielli (2004, p. 45) marks the line between 'communication-transmission' and 'communication participation'; he considers the last motive as typical for French SIC. Apart from these oversimplifications, the two communities of communication scholars, German and French, share in fact many common grounds, for example the debate on the 'boundaries' of the discipline and the question whether it would not be an inter- or a transdiscipline (for Germany see Saxer, 1993; for France see Jeanneret, 2001).

\section{FRAME OF REFERENCE}

Our knowledge of international comparison of communication studies is still limited. There are some studies which deal - more or less isolated - with single countries (for France Boure, 2002; Jeanneret \& Ollivier, 2004; Oliviesi, 2006; Puustinen, 2007; for Spain Jones, 2001; for the Netherlands Klein, 2006; for Switzerland Jarren, 2000; Süss, 2000; Göppner, 2005; Schade, 2005; for Austria Fabris, 1983; Duchkowitsch \& Hausjell, 1993; Monschein \& Randl, 1996; for Finland Pietilä \& Malmberg \& Nordenstreng, 1990; for South Korea Kim \& Westerbarkey, 1998; for South America Massmann, 2004; for Japan Schäfer, 2005; for several Arabian countries Hammami, 2005). Mostly, it is communication research in the United States which is taken as a point of reference for comparisons. It was the UScommunication research which was most influential worldwide - while researchers like Lazarsfeld, Lewin or Festinger have been emigrants from Europe (Reimann, 1990).

\footnotetext{
${ }^{3}$ Katz himself doesn't refer to Germany nor France, but mainly to the US.
}

Caused by sometimes extremely different influences on science (from culture, from political system and politics, from technology), a clear cut comparison of two different cultures of communication science seems nearly impossible. I tried to develop a frame of reference which is abstract enough to find common grounds to compare different cultures of sciences ${ }^{4}$ and at the same time helps to reflect on concrete dimensions as well as interdependency. There is not much interdependency between French and German Communication Studies ${ }^{5}$ but there are common citation lines, especially via the US-communication research, and some theoretical settings which gained attention worldwide (like pragmatism and social behaviourism, cybernetics and system theory).

My methodological concept refers to a 'phase model' dedicated from studies in the history of science, referring to the German community of communication research by Arnulf Kutsch and me (Averbeck \& Kutsch, 2002). ${ }^{6}$ Another

\footnotetext{
${ }^{4}$ This also includes clashes in style. The French SIC are much more 'literal' in their expression than German Kommunikationswissenschaft (Saxer, 2000; Averbeck, 2000). For intercultural differences in scientific styles, thinking, and methodology see Galtung (1983).

${ }^{5}$ For an exception see the papers of the Paris-Munich Colloquium invented by Ursula E. Koch, Detlef Schröter and Pierre Albert (e.g. Albert \& Freund \& Koch, 1990; Albert et al., 2003). - I do not subsume the adaption of French (Post)structuralism and media philosophy in German media studies under 'Kommunikationswissenschaft': Thinkers like Jean Baudrillard, Guy Debord, Paul Virilio, Régis Debray who are in fact sociologists or (media) philosophers are widely cited in German 'Medienwissenschaft' (see e.g. the biographic articles on French thinkers in Schanze, 2002). For further details on differences in denomination of 'media science' in Germany and France and 'mediology' around Debray as a field of research on its own, separated from French SIC, see Linde, 2005.

${ }^{6}$ Our scheme was reorganised by Meyen and Löblich in 2006 (Meyen \& Löblich, 2006, pp. 30-31). Meyen and Löblich focus more on a biographical approach to the history of science; Kutsch and me refer to generations of scholars. For further discussion on the operationalisation of the aims of the sociology of science under generative aspects see Koenen, 2007; Lacasa, 2007; Meyen, 2007.
} 
reference is the sociology of science, especially Peter Weingart's notion of 'Denkmotiv' ('underlying concept') and Dirk Käsler's 'Ideen- und Sozialgestalt' ('corpus of ideas and social corpus of a science' (Weingart, 1976; Käsler, 1984). Many hints, concerning the epistemology and sociology of science, especially in France, I owe to the rich and fruitful work of Wolf Lepenies $(1981 ; 1988 ; 1989)$.

External and internal factors are highly interwoven; the social corpus of a discipline is stratified in more or less strong connections with external factors as well as internal factors (competition for resources, but also for the acceptance of ideas, models, methods and theories) (Kuhn, 1976; Latour \& Woolgar, 1979).

Those general items are applicable to the history of communication studies in Germany as well as in France, because they are formal categories which have to be filled with empirical data. Sources may be archive materials from involved (corporate) actors and institutions to reconstruct the social corpus and - on the other hand - publications to reconstruct the corpus of ideas. We have to take into account especially such publications which show the debates in the field, e.g. scientific journals, member bulletins of the main professional organizations of scholars in the field, the papers of the meetings of those scholars.

\section{GERMANY}

Primary sources of my work on 'Zeitungswissenschaft in Weimar Republic' were rich archive materials (from university archives all over Germany) for reconstructing the social corpus of that science. For the corpus of ideas, sources were the first scientific journal in the field called Zeitungswissenschaft (1926-1944), the dissertations on communication problems which were supervised at some leading universities in the field between 1925 and 1935, those monographies and articles in the field which emerged in a citation and contact milieu between Zeitungswissenschaft and sociology. The workings in this circle of younger scholars and PhD-students I could identify as very promising under theoretical aspects (this milieu did not longer exist when the Nazis came into power) (Averbeck, 1999).

Our case studies in the history of ideas and institutions of German Zeitungs- and Publizistikwissenschaft in the first half of the $20^{\text {th }}$ century motivated Arnulf Kutsch and me to think about a general heuristic model to classify the history of communication research in Germany before 1970 (Averbeck \& Kutsch, 2002). The $1970^{\text {ths }}$ mark a break insofar as the old Publizistikwissenschaft became Kommunikationswissenschaft and drifted from historical and hermeneutical approaches to a social science (Bohrmann, 1997; Kutsch \& Pöttker, 1997; Klein, 2006; Wilke, 2006; Löblich, 2007).

In this model, Kutsch and I thought about: actors (scientists, organizers of science, politicians) and structures (organizations, journals, meetings, a 'scientific community'). We thought about analytical concepts of German Zeitungs- und Publizistikwissenschaft, including their underlying normative motives and value systems and also about 'breaks' in the German history of communication studies. For classifying the institutional stages, we used Terry N. Clarks scheme which marks steps from 'solitary science' over 'amateur science', 'emerging academic science', 'established science' to 'big science' (Clark, 1974). ${ }^{7}$ Breaks, we argued, had been induced by internal and external forces; external forces were mainly economic and political ones. The overwhelming break was introduced with Nazi-Newspaper Science - which was not an invention of the politicians of the "Third Reich" (nor the Ministry of Propaganda). On the contrary, it resulted from motivations that came mainly from the core of Zeitungswissenschaft itself: it was a 'Selbstgleichschaltung' with the Nazi ideology, not some kind of external banner which caused the loss of highly modern ideas of Weimar Zeitungswissenschaft on the formation of public opinion (Bohrmann \& Kutsch 1975/76; Hausjell, Duchkowitsch \& Semrad, 2004; Kutsch, 1984; Averbeck, 1999, pp. 102-144; Averbeck, 2001; Averbeck \& Kutsch, 2002; Koenen, 2007a). The break was initiated by young scholars, many of them convinced Nazis, some of them careerists who took their profits from the forced emigration of their former colleagues or pupils (for the emigration of scientists in newspaper and media studies to the US and other countries see Kutsch, 1988; Wilke, 1991; Averbeck, 2001). After the 'Third Reich', the German Zeitungswissenschaft as a whole was blamed, the output of the discipline, like the 'Handbuch der Zeitungswissenschaft', speaks a language of totalitarian ideas, Antisemitism, racism and strong stimulus-response perspectives on communication, especially propaganda (Bohrmann \& Kutsch, 1979; Hausjell et al., 2004; Kutsch, 2006). It was not easy to (re)build Publizistikwissenschaft in Germany (Bohrmann, 1997; Kutsch \& Pöttker, 1997; Klein, 2006; Wilke, 2006; Löblich, 2007). As Hardt outlined, the Nazi past of German Zeitungswissenschaft led to a strong positivistic attitude and to a ban on philosophical traditions in the field (Hardt, 2002) - as if the Germans would have to ensure that no ideology would ever again get a chance to infiltrate their thinking on communication. During the Weimar Republic, Newspaper Science was dominated by historical approaches, but also phenomenological ones, some of which integrated semiotics (Traub, 1933). Young scientists who shared a common milieu between Zeitungswissenschaft and sociology explained that communication might be a process between two poles: professional journalism and its readership or the audience. It was supposed that the attitudes of the audience were developed in a rich socialization process here we find the first reflections on intervening variables in the mass communication process, namely from Walter Auerbach, Hans Traub, Ernst Manheim and Gerhard Münzner (Averbeck, 1999; Holtz-Bacha \& Kutsch, 2002). This is the forgotten past of the German tradition. Nowadays, German Kommunikationswissenschaft has to be described mainly as empirical social research on mass communication with strong input from the 'classical' US-American tradition (Lasswell, Hovland, Lewin, Lazarsfeld). In my opinion, the orientation of German Kommunikationswissenschaft towards the US was also a remedy to forget the Nazi past as soon as possible, and to find out how to measure 'reality' (and not to built up ideologies...). The rich culturalistic tradi-

\footnotetext{
${ }^{7}$ To Clark are also referring, Averbeck (1999, p. 43) for a classification of Zeitungswissenschaft in the Weimar Republik, Koenen (2005) for classifying the 'solitary' position of Erich Everth who held the only chair in newspaper science in Weimar-Germany and Wilke (2006) for the whole range of the history of Kommunikationswissenschaft in Germany.
} 
tion in the field of communication studies in the US came to Germany only from the $1980^{\mathrm{s}}$ onwards or later, when the empirical social science attitude had been tightened. German Kommunikationswissenschaft mainly consists of empirical social research in the fields of the uses and effects of mass communication, with a strong impact on quantitative content analysis in the tradition of Bernard Berelson. This is very well documented by a quantitative content analysis of the leading journals in German communication studies: Publizistik and Medien \& Kommunikationswissenschaft (Donsbach/Laub et al., 2005). The declaration of aims of the Deutsche Gesellschaft für Publizistik- and Kommunikationswissenschaft (DGPuK) excludes interpersonal communication from their schedule if it is not linked to or involved in the mass communication process (DGPuK, 2001). This selfrestriction actually causes a new debate on the boundaries of (German) communication studies and on perhaps widening the field, as well as concerning the subject of communication studies and the methodology, which is regarded by some members of DGPuK as too narrowly focused on quantitative research and mass communication (see for example Aviso, No. 35/2004). This is an ongoing debate. The new self decalration of the DGPuK is announced to be published in $2008^{8}$

Table 2. Phases of Communication Studies in Germany Since 1916
The following periodization is based on the phase model of Kutsch and me (2002), but it is not identical: I extended our 4-phase model to seven phases.'

This model has to be considered as a heuristic one. Only the first three phases are well explored on a sufficient data base (Averbeck, 1999; Averbeck \& Kutsch, 2000; Averbeck \& Kutsch, 2005; Benedict, 1986; Große, 1989; Groth, 1948; Hausjell et al., 2004; Hachmeister, 1984; Heuser, 1994; Klose, 1989; Kutsch, 1984; Kutsch, 1985; Lacasa, 2007; Meyen \& Löblich, 2004; Roegele \& vom Bruch, 1986; Straetz, 1984; Szyska 1990). Detailed work on the more recent history of the discipline is outstanding, but there are some efforts: Arnulf Kutsch's and Horst Pöttker's edition of autobiographic views on phase 4 and 5 (Kutsch \& Pöttker, 1997); Petra Klein's dissertation on the Prakke School (Klein, 2006), Bernd Sösemann's books on the era of the professorships of Emil Dovifat and Fritz Eberhard at the Free University of Berlin (Sösemann, 1998; Sösemann, 2001), Jürgen Wilke's edition on Publizistikwissenschaft at the University of Mainz (Wilke, 2005) as well of the edition of Michael Meyen and Maria Löblich on Zeitungswissenschaft at the Munich Institute (Meyen \& Löblich, 2004); Maria Löblich's reconstruction of the work of Otto B.

\section{IDENTIFICATION OF PROBLEMS (1916-1925/26)}

social corpus: solitary and amateur science

first Institute for the Studies of the Press at University of Leipzig, 1916

corpus of ideas:

> perspectives of the mother disciplines history, economics, literature press history, press law, press economics

nature of the press'/definition of the press: periodicity, publicity,

universality, timeliness

cultural and political value of the press, journalism and public opinion

(e. g. Emil Dovifat's dogma of 'publizistische Persönlichkeit' - typing the journalist as a 'publicistic personality')

influence of the press on public opinion

(e. g. Emil Dovifat's dogma of 'Einhämmerung' - to hammer the information to the public)

2. DEFINITION OF PROBLEMS (1925-1935)

social corpus: (emerging) academic science

Between 1916 and 193219 academic unities (institutes, little departments, only one chair at Leipzig) emerged $^{10}$

corpus of ideas

> perspectives of newspaper science sui generis, public opinion

the role and function of journalism in society

journalism as a profession 'nature of the public'

(e. g. Gerhard Münzner's differentiation of masses, crowd, public and peer groups)

(e. g. Gerhard Münzner's, Hans Traub's, Walter Auerbach's, Ernst Manheim's concepts on audience selectivity caused by peer group influences, political interest and education)

functions of the press and radio

(e. g. Erich Everth's dogma of 'Vermittlung ${ }^{11}$ - intermediation of different publics via press, e.g. Hans Traub's dogma of media as 'geistiger Zwischenverkehr', a 'cognitive interrelationship" between people)

\footnotetext{
${ }^{8}$ This was announced at the latest yearly congress of DGPuK in Bamberg in May 2007. See also http://www.dgpuk.de (12.6.2007).
}

\footnotetext{
${ }^{9}$ This model refers to a huge amount of primary and secondary literature (most of it can be found in the bibliography of this article; I only mark my sources of information directly in the model insofar as not yet cited).

${ }^{10}$ See in detail Averbeck, 1999, pp. 54-65.

${ }^{11}$ For Everth see Bohrmann \& Kutsch, 1979; Averbeck, 2002; Koenen, 2005.
} 
Table 2. contd....

\begin{tabular}{|c|c|}
\hline \multirow[t]{7}{*}{ 3. IDEOLOGY } & (1933-1945) \\
\hline & social corpus: established science \\
\hline & $\begin{array}{l}\text { expansion of the institutional corpus of 'Zeitungswissenschaft' (fund raising from the National Ministry of } \\
\text { Propaganda), organization and standardization by 'Deutscher Zeitungswissenschaftlicher Verband' (DZV) } \\
\text { corpus of ideas }\end{array}$ \\
\hline & >> perspectives derived from political and ideological standpoints, conform to the state \\
\hline & $\begin{array}{l}\text { Legitimation of propaganda, reducing of the public to 'Volksgemeinschaft' (Nazi-ideology), declaration of } \\
\text { press as a 'Führungsmittel' (a central 'leading' social force) }\end{array}$ \\
\hline & >> abolishing of the sociological perspectives of phase 2 \\
\hline & press history (glorifying the German press history) \\
\hline \multirow[t]{6}{*}{ 4. RECONSTRUCTION } & (1945-1960) \\
\hline & $\underline{\text { Social corpus: }}$ academic science under reconstruction ${ }^{12}$ \\
\hline & (only a few institutes and departments were not closed) \\
\hline & $\underline{\text { corpus of ideas }}$ \\
\hline & $\begin{array}{l}\text { > The aim to rebuilt scientific perspectives for 'Publizistik' as the science of public communication via mass } \\
\text { media (e.g. Walter Hagemann's approach of 'systematical publicistics") }\end{array}$ \\
\hline & $\begin{array}{l}\text { The phenomenon of propaganda and political influence via mass media } \\
\text { market research and opinion polls (Elisabeth Noelle-Neumann) }\end{array}$ \\
\hline \multicolumn{2}{|c|}{ 5. REDEFINITION: EMPIRICAL SOCIAL SCIENCE RESEARCH (1960-1980) } \\
\hline & $\underline{\text { Social corpus: emerging and established science }}$ \\
\hline & (new institutes emerge) \\
\hline & corpus of ideas: \\
\hline & $\begin{array}{l}\text { 'Publizistik' remains a leading motive (e. g. Henk Prakke's 'funktionale Publizistik' - 'functional publicistics' } \\
\text { - with a strong impact on social communication, including interpersonal and nonverbal communication); }\end{array}$ \\
\hline & $\begin{array}{l}\text { School of Munich Press Science ('Münchner Zeitungswissenschaft') on social communication and its motive } \\
\text { that public communication is filtered by social organisation, adaption of US-communication research (e. g. by } \\
\text { Gerhard Maletzke who invented his famous 'field model of the mass communication process, public opinion } \\
\text { (e. g. Noelle-Neumann's spiral of silence), applied research forced by political and economic demands }{ }^{13}\end{array}$ \\
\hline \multicolumn{2}{|c|}{ 6. DIFFERENTIATION OF RESEARCH FIELDS, SUBJECTS AND APPROACHES (1980-1990) } \\
\hline & 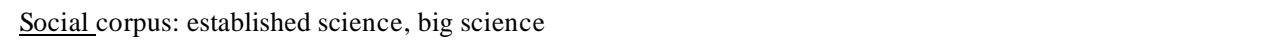 \\
\hline & corpus of ideas: \\
\hline & $\begin{array}{l}\text { 'Publizistik' is no longer the leading motive, but 'communication', especially 'public communication", influ- } \\
\text { ence via mass communication on public, as well as uses of mass media; }\end{array}$ \\
\hline & Funktionale Publizistik is loosing ground \\
\hline & School of the Munich Press Science is loosing ground \\
\hline & $\begin{array}{l}\text { combinations of communicator- and audience research, new theoretical setting: 'Dynamisch-transaktionaler } \\
\text { Ansatz' by Werner Früh/Klaus Schönbach } 1982\end{array}$ \\
\hline & orientation versus system theory \\
\hline & (e. g. Manfred Rühl's 'Redaktion als soziales System' 1969, influenced by the work of Niklas Luhmann) \\
\hline & orientation versus actor theory \\
\hline & $\begin{array}{l}\text { (e. g. Carsten Renckstorf's and Will Teichert's 'Nutzenansatz' up from the late 1970ths referring to Max We- } \\
\text { ber's theory of social action) applied research: standardized methods are survey and content analysis }\end{array}$ \\
\hline & adaption of US-research in agenda setting, uses and gratifications, knowledge gap hypothesis etc. \\
\hline \multirow[t]{11}{*}{ 7. NEW THEORETICAL SETTINGS } & (1990 till today) \\
\hline & 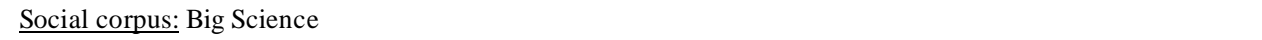 \\
\hline & (caused especially by a constant demand of students) \\
\hline & corpus of ideas: \\
\hline & systems theory \\
\hline & (e. g. Frank Marcinkowski's 'Publizistik als autopoietisches System') \\
\hline & radical constructivism ('School of Münster' with Klaus Merten and Siegfried J. Schmidt) \\
\hline & actors theory / interactionism \\
\hline & $\begin{array}{l}\text { (e. g. Roland Burkart's view on 'verständigungsorientierte Kommunikation' following Mead and Habermas or } \\
\text { Friedrich Krotz's integration of Uses and gratifications and Symbolic Interactionism) }\end{array}$ \\
\hline & Cultural Studies \\
\hline & $\begin{array}{l}\text { (e. g. Andreas Hepp's view on international and intercultural communication; Margreth Lünenborg's approach } \\
\text { to communicator studies) } \\
\text { following Averbeck/Kutsch, } 2002\end{array}$ \\
\hline
\end{tabular}

${ }^{12}$ Wilke classifies the 'starting position' of German Publizistikwissenschaft after 1945 (which in fact was not a new start) as 'emerging' science. Like me, he refers to the stages of Clark (Wilke, 2006, p. 320). In my opinion the term 'emerging science' is not clear enough to classify this stage compared with phase 13.

${ }^{13}$ This is exemplified by Maria Löblich on the case of the study programme in media politics by the government of the Federal Republic of Germany up from 1970 (Löblich, 2007a). 
Roegele (Löblich, 2004); currently she is working on the epistemological debates on 'Publizistik- versus Kommunikationswissenschaft' around 1960 (Löblich, 2007).

\section{FRANCE}

In France, the Sciences de l'information et de la communication (SIC) ${ }^{14}$ emerged in the mid $1970^{\text {ths }}$ from the mother discipline literature, respectively linguistics, and not from (press) history, (press) law, sociology (of the press) and (press) economics as in Germany, after World War I. Anyhow, there also have been strong influences from the lastmentioned ones, especially press history and law (Albert, 2001; Balle \& Cappe de Vaillon, 1983; Delporte, 1999; Gritti, 1999; Mercier, 1994; Ruellan, 1997). Reversely, in Germany the sciences concerned with literature had not been the main influence on the upraising discipline in the $1920^{\text {ths }}$. - Only to mention here, that the $1970^{\text {ths }}$ and the $1920^{\text {ths }}$ are as hardly to compare as the environment of the institutionalization processes of communication studies in the two countries.

Indeed, it was a Professor for Comparative literature, Robert Escarpit (1918-2000), who has to be considered as the institutional founding father of SIC. He established the First Institut Universitaire Technologique (IUT) for communication in 1967 at the University of Bordeaux, which has been copied in the following years by other French universities. He initiated the Comité Français pour les Sciences de l'information et de la communication which succeeded in pushing the political administration to install SIC as a discipline in 1975 (Escarpit, 1992; Robine, 2001). The strong external factor for the implementation of this new discipline was the aim of the politicians to reform the Sorbonne and to implement education programmes into the French University which were oriented to the professions of the new 'Société de l'information' (Miège, 2000, p. 558; CNE, 1993). From those days onwards, the generation of the founding fathers, like Robert Escarpit, and their successors have been confronted with the double character of SIC: it has to fulfill mainly practical aims for society (external means) and at the same time research aims (internal means). Such problems are also not unknown in Germany - but in the French debates in the inner circles of SIC, this problem is much more highlighted (CNE, 1993, p. 70). ${ }^{15}$ The cause might be that German 'Zeitungswissenschaft' was installed for other reasons and in another historical context (World War I and the 'failure' of the German Press, see below) than French SIC (shift from the industrial to the postindustrial, so called media society). Zeitungswissenschaft was not installed into the German University for special training in journalism ('Ausbildung'), but for a general education on the function of press in society ('Vorbildung'). Up from the beginnings of 'Zeitungswissenschaft' - 90 years ago - the academic staff struggled for acceptance of the faculties and neighbor sciences (Bohrmann, 1986); French SIC are looking backwards on a history of only 30 years - including such acceptance problems.

\footnotetext{
${ }_{15}^{14}$ The abbreviation SIC is widely used in France, so I do here.

15 Perhaps the so-called Bologna Process will diminish differences presumably to a more practical orientation of studies in Germany, too.
}

In the Committee for the French SIC, Escarpit was accompanied by Roland Barthes (1915-1980) and Jean Meyriat (born in 1921). At that time, Barthes worked together with Georges Friedmann (1902-1977) and Edgar Morin (born 1921) at the Centre d'Etudes de Communications de Masse (CECMAS, founded in 1962) at the famous Ecole des Hautes Etudes en Sciences Sociales (EHESS). This milieu was in fact a melting pot of people and ideas: Barthes with semiology, Friedmann with the sociology of work and leisure, Morin with the sociology of pop culture and later on with his focus on cybernetics, systems and complexity (for details of the history of the SIC, including CECMAS see Averbeck, 2000; Averbeck, 2005; Escarpit, 1992; Devèze, 2001; Meyriat, 1994; Mattelart \& Mattelart, 2002; Tétu, 2002; Vroons, 2005). Jean Meyriat, the third committee member, was an information scientist working in the field of book science (Couzinet, 2001). The name of the field 'communication and information science' was not an accident, but a strategy: The founding fathers bundled different branches of 'one' (?) field: 'Le terme de SIC est finalement conservé pour des raisons d'efficacité: le sentiment prévaut que le mot plus concrèt 'd'information' précise un peu la notion vague de 'communication'; ce couplage permet en même temps de servir les intérèts de plusieurs groupes distincts de spécialistes, sans prendre une position définitive sur l'épistémologie du domaine' (Meyriat, 1994, p. 7). Information science lost ground in the SIC during the 1980s and differentiated own institutional structures (Palermity \& Polity, 2002).

After World War II, the Rockefeller Foundation aimed to implement the American model of social science research (widely influenced by Lazarsfelds 'administrative research') in Europe. Their underlying aim was a normative one: to stabilize democracy via social science research (Pollak, 1990). In its first years, the CECMAS at Paris was cofinanced by the Rockefeller Foundation. Lazarsfeld advised Friedmann, Morin and Barthes how to built up research teams (Revel \& Wachtel, 1996, p. 15; Souchon, 2004). That is the institutional line. In fact, French communication studies always have been sceptical about US-social science functionalism. Structuralism has been considered incompatible with functionalism and positivism. The cultural meaning of communication is underestimated in functionalism, one argues (Morin, 1972, pp. 97-98; Boure, 2002, p. 11; Maigret, 2004, pp. 113-114). Communication is a circular, transactional process, not a linear one, as approaches from Eliséo Véron and Patrick Charaudeau are revealing (Véron, 1981; Véron, 1987; Charaudeau, 2006). That way of thinking can also be found in the American tradition. It is what James W. Carey calls the 'ritualistic view' on communication, in contrast to the 'transmission view' of the Lasswell/Lazarsfeldtradition (Carey, 1992, p. 19). So, one might argue, there might be a strong line from French SIC to today's British and North American Cultural Studies. But that is not the case why? My hypothesis is that the culturalistic view is integrated so strongly in the French tradition itself that Cultural Studies were of small significance. Not to forget: Cultural Studies themselves refer to the French tradition of semiotics (Hepp, 2004, pp. 25). Réseaux had published a framework of texts of the Birmingham Centre for Contemporary Cultural Studies in 1996 (Réseaux, No. 80). It was not before 2003 that Erik Neveau and Armand Mattelart published a monographic introduction to Cultural Studies (Mattelart \& Neveu, 
2003). The circle of influences is closing: the search for 'shared meaning' is widened by looking for approaches to explain this phenomenon in the anglo-american hemisphere.

In Germany, Cultural Studies miss broader acceptance in the field of communication studies (Schwer, 2005). This is no accident: the traditions of Zeitungs- and Publizistikwissenschaft with their strong view on influence and power, transmitted via mass media, do not focus on the 'ritualistic view of communication' mentioned by Carey (see above) or 'sens' - the main paradigma of French SIC. ${ }^{16}$

As my research on France is mainly on the corpus of ideas, the social corpus of the discipline is not integrated in the following phase model. ${ }^{17}$ In fact, we see the same dimensions as in Germany: 'amateur science' by some academics and journalists since the beginnings of the $20^{\text {th }}$ century (Albert, 2001; Delporte, 1999; Mercier, 1994; Ruellan, 1997), the 'solitary science' of professors and lecturers - mainly at the Paris Centre d'études de communications de masse (CECMAS), the Institut unversitaire Technologique (IUT) Carrières de l'information at University of Bordeaux and the Institut Francais de Presse (IFP) - before the 'established' discipline emerged, and 'big science' with highly differentiated institutes today. Compared with Germany, the first phases did not lead directly to any larger institutionalisation, but only the initiative of Escarpit at the beginnings of the $1970^{\text {ths }}$. Obviously, the social demand on science was not as strong as in Germany, decades before. We know that the implementation of newspaper science in Germany to a great part was caused by the assumed loss of the 'press war', between 1914 and 1918 - assumed by politicians, public, journalists and publishers. The latter ones, at least, gave strong fund raising to build up 'Zeitungswissenschaft' (Averbeck, 1999, p. 46; Bohrmann, 1986, pp. 95-97, p. 99). For France, it was the huge modernization of administration, universities, professions and the media sector after 1968 which was the dominant external influence (Cazeneuve, 1972, p. 371; CNE, 1993). Balle and Cappe de Baillon outline a tabula rasa situation even in the $1970^{\text {ths }}$ : 'In most countries, media research was periodically supplied with data from sample sur-

\footnotetext{
${ }^{16}$ Two typical citations may illustrate this: 'A un niveau très général, on peut distinguer trois pôles, trois dimensions dont toute recherche en communication cherche à élucider les rapports: celui de circulation de sens, celui des acteurs et des pratiques sociales, celui des techniques [...]. Les Sic sont la discipline qui s'interesse prioritairement aux relations croisées que chacun de ces termes entretient avec les deux autres. Son originalité est de construire des axes de recherche guidé par l'intention de traîter conjointement ces dimensions que les spécialisations traditionelles laissent séparées: comment faire se rejoindre les signes et les supports, les acteurs le les objets, les situation et la génération du sens.' (Perret, 2004, p. 126). '[...] la communication est un concept qui désigne un processus social qui s'étend à tous les êtres humaines, [...], selon lequel l'échange d'information sur un sujet donné conduisant à un partage de sens se fait en mettant les personnes en contact, en interaction' (le Coadic, 2006, p. 5).

${ }^{17}$ For the phases 1-3 in Germany my own research is based on archives sources; I did not undertake such research for France, but I exploited $\mathrm{La}$ lettre d'inforcom. Bulletin de la Société française des Sciences de l'information et de la communication (1978-2003) for the same aim: to look after the growing of the discipline as well as its breaks. The member bulletin is an excellent source for a first reconstruction of the institutionalization of SIC; of course it is not a sufficient one; archive studies are needed. - Balle and Cappe de Baillon are mentioning an interesting break, which - as far as I know - not yet has been a cause for research until now: The Institut français de presse (IFP) and also the Institut francais de l'opinion public (IFOP) closed during World War II (Balle \& Cappe de Baillon, 1983). Why? Was this caused by the German occupators?
}

veys and polls. In France, radio and television developed slowly for both, technical and political reasons, so there was little to survey or poll' (Balle \& Cappe de Baillon, 1983, p. 146).

Sources of my qualitative hermeneutic research for the corpus of ideas of SIC are the leading peer reviewed journals in the field in France Réseaux (founded in 1983) ${ }^{18}$ and Hermès (founded in 1988), ${ }^{19}$ the member bulletin of the Société Française des Sciences de l'information et de la communication (SFSIC) La Lettre d'inforcom. Bulletin de la Société Française des Sciences de l'information et de la communication $(1975-2003)^{20}$, the collected papers of the biannual meetings of the SFSIC (1978-2004), and monographies on theory and theory building in the SIC.

For the corpus of ideas in French SIC, I propose the following, only rudimentary, abstraction, reduced on leading motives of theory building, methodology and research. The history of the Sciences de l'information et de la communication is not yet written - neither for any of its institutes nor its phases.

While we have to deal with the more or less rigidly formulated field of mass communication research in Germany, there is no such 'mainstreaming' in French SIC. As Gerhard Kopper mentioned: 'Das Land [Frankreich], in dem eine rigorose und zentral administrierte Klassifikations- und Nachwuchspolitik für das in den siebziger Jahren eingeführte Fachgebiet ,science [sic!] de l'information et de la communication' herrscht, erfreut sich eines nahezu ausufernden Themen- und Perspektivreichtums sowie erheblicher Methodenvielfalt in der Forschung. Das Land hingegen, in dem sich die Disziplinen völlig frei von zentraler Aufsicht inzwischen mit Fragen der Medien und Kommunikation befassen, zeichnet sich durch hohe Rigorosität in der Methodenanerkennung innerhalb einzelner Fachgruppen aus' (Kopper, 2004, pp. 103-104).

The cause lies in the focus of communication problems. The SIC knew the heritage of US-American communication studies (Balle \& Padioleau, 1972; Béaud, Flichy et al. 1997; Lazard, 1991; Lazard, 1992; Mattelart \& Mattelart, 2002; Rieffel, 2001), but at the same time they developed their own focus on communications studies, its research fields and problems (see also Pietilä, Malmberg, \& Nordenstreng, 1990). ${ }^{21}$ The early focus at CECMAS might have been programmatic: they worked together with Lazarsfeld, but at the

\footnotetext{
18 Réseaux emerged as a bulletin for the members of a research group around Patrice Flichy at the laboratory of Centre Nationale de Télécommunications (CNET) in 1983; I thank the archive of France Télécom at Issy les Moulineaux, especially Jean-Pierre Bacot, secretary of Réseaux, for the possibility of consulting those 'non official' numbers of the journal, which was available by book trade up from 1989.

${ }^{19}$ For the centrality of those journals see Maigret (2001).

20 The last number of La lettre d'inforcom was published in 2003. See also http://www.sfsic.org (28.5.2007). Up from June 2007 the SFSIC is editing a new member bulletin: Les cahiers de la SFSIC.

${ }^{21}$ Pietilä, Malmberg and Nordenstreng present a three-variant-model for international comparisons in communication research: A 'EuropeanAmerican'-variant (empirical social research, functionalism), a 'French'variant (semiotics) and a 'German'-variant (Zeitungs/Publizistikwissenschaft). The model has its strong historical momentum, but nowadays nor the French nor the German variants are describable on such a restricted level: French SIC has gone to "Post-Semiotics" (SemioPragmatics, Social constructivism). German Kommunikationswissenschaft broke up with Publizistikwissenschaft.
} 
Table 3. Phases of Sciences de L'information Et De La Communication (SIC) Since 1975

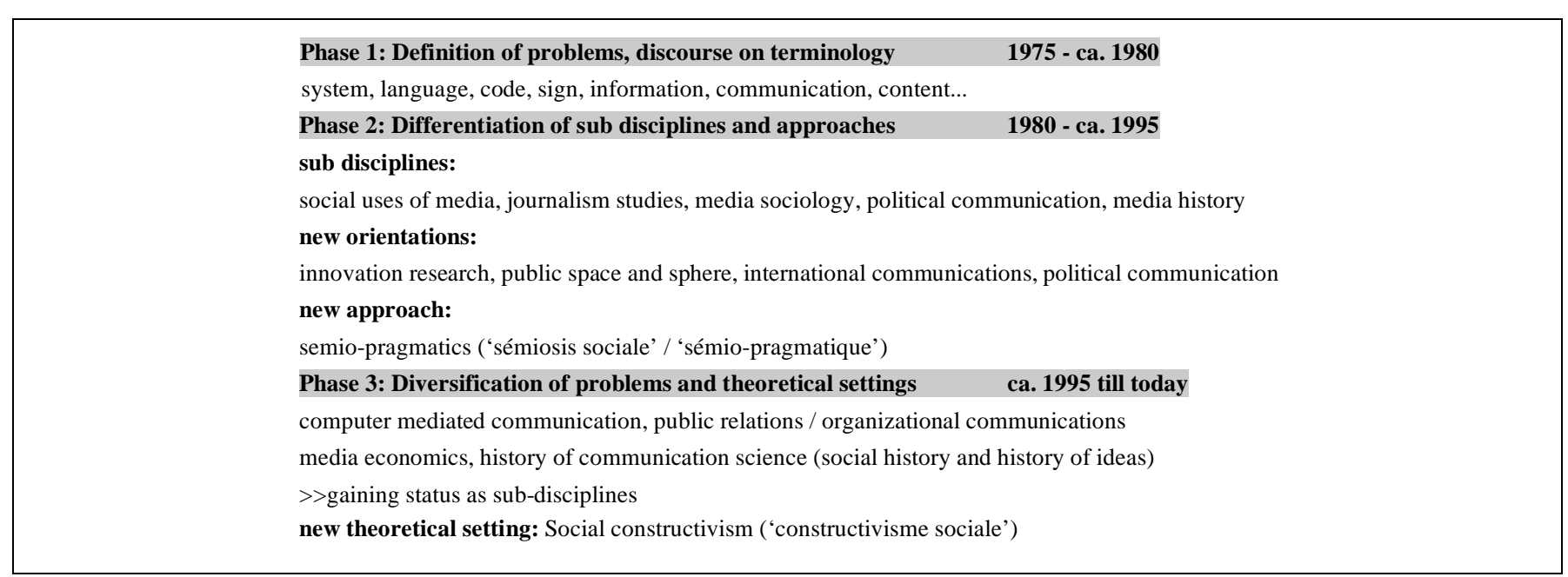

same time they opened the field to social communication in its broadest sense: Barthes's semiology forced his pupils to think on the semiotic bases of communication processes. Such traces can be found for example in the work of Eliséo Véron (born in 1938) who himself inspired a younger generation (for example Alex Mucchielli, Jean-Jacques Boutaud) to think about semio-pragmatics. Here the corpus of ideas and of institutions clash: Véron was not only a pupil of Roland Barthes and Christian Metz (1931-1993), but he spent some research time at Palo Alto in the Mental Health Institute. His semio-pragmatics is at least a fusion of ideas from Barthes over Peirce to Mead, Bateson and Watzlawick (see e.g. Véron, 1988). We can not outline this in detail here. ${ }^{22}$ Semiopragmatics which can be assigned also to Patrick Charaudeau and Roger Odin is not a closed theory, it is an eclectic approach of thinking social communication (for an introduction see Béaud \& Kaufmann, 1998).

While Bernhard Debatin mentions for Germany that Kommunikationswissenschaft shortens Watzlawick to his "five axioms" (Debatin, 2002), this is not the case in the French community, where the full epistemology of Palo Alto (not only derived from the work of Watzlawick himself, but also from Bateson and Birdwhistell) has a strong heuristic impact on communication theory, especially on the notion of interaction systems. Véron derives from Bateson, Watzlawick and - last but not least - Mead the idea that communication is an interaction process embedded in language and non verbal communication. Consequently sensemaking is supposed to be a co-construction between actors. But not: a subjective construction nor a construction determined by society, 'symbols' or 'discourse' as held by Barthes or Foucault. Véron is clearly breaking with the structuralist paradigm (Véron, 1987). Véron's concepts are not too far from Berger and Luckmann's 'construction of social reality' and they share the reference on Mead (Berger \& Luckmann, 1994). Berger and Luckmann are also present in French SIC, for example in the writings of Alex Mucchielli, he himself an adept of Véron and Watzlawick. Mucchielli is

\footnotetext{
${ }^{22}$ I refer to my forthcoming habilitation project.
}

one representative of social constructivism in France (Muchielli, 2004). ${ }^{23}$

The concept of 'semiosis social' (Véron) in the version of semio-pragmatics leads to the social construction of reality; each actor takes part in it, but is not completely free in his interpretation: meaning is always a socialized process, mass media are only some (but strong) vectors of this socialization. At the same time they are themselves embedded in the societal process as a whole (Véron, 1981). No reader, viewer, listener and no communicator is completely autonomous. The linkage between reception and social construction in France is a direct heritage from structuralism - but from its criticism. One may read this in detail in the works of Patrick Charaudeau, Louis Quéré or Eliséo Véron. The latter argues with Mead against his own teacher Roland Barthes that Semiosis is not only the processing of meaning by discourse or an underlying 'structure' which is determining individual action. Meads ' $I$ ' is taking its creative role in the construction of meaning and the ongoing deconstruction of structures which are at the same time under permanent and dynamic reconstruction via inter-action.

We see: There is a strong adaption of American social philosophy and social science in French semio-pragmatism. This is the line of reception France - USA which is interesting to understand. It is not only canalized by citation milieus but by direct personal connections which are a constructive external/internal element of those citation milieus: Via his followers, Eliséo Vérons American experience 'Palo Alto' was widely influencing French Sciences de l'information et de la communication. In the mid $1990^{\text {ths }}$ Véron went back to his home country, Argentina, where he today holds a professorship in communication studies. He once emigrated from Argentina to France in times of dicatatorship in his home country - external means of his scientific biography. ${ }^{24}$

Beyond theory building, we find early empirical research in France on social communication, including media gener-

\footnotetext{
${ }^{23}$ For Mucchiellis work in the field of corporate communications see Hopfe (2007).

${ }^{24}$ See Curriculum Vitae Eliséo Véron. Website of the National Research Foundation of Brazil. Retrieved June 10, 2007 from the World Wide Web: http://busatextual.cnpq.br/.
} 
ated interpersonal communication via telephone and the famous Minitel. ${ }^{25}$ It was the social science laboratory at the Centre National des Télécommunications (CNET) which brought onwards empirical research on social uses of media in the whole context of every day live and leisure and widely influenced the SIC (Jouet, 2000). This laboratory, directed by the sociologist Patrice Flichy (born in 1945) for 15 years, should be a research theme on its own. At the CNET, we find applied research as well as fundamental research; here external factors (resources from France Telecom, research on new technical developments) and internal factors of science again clash: In 1983 Patrice Flichy invented Résaux which became one of the leading journals in the field of communication studies. In 1999 he left the CNET for a professorship in sociology at the University of Marne la Valée; he is still editing Réseaux. ${ }^{26}$

\section{SYNTHESIS}

The following table may serve as an heuristical concept.

\section{Table 4. Concepts of thinking communication in Germany and} France

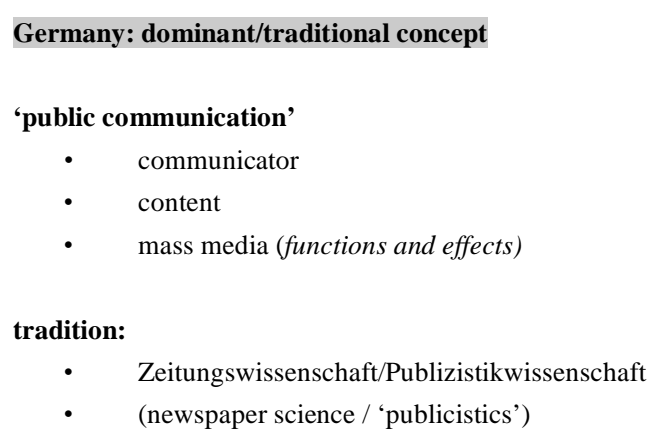

France: dominant/traditional concept

'social communication'

- communication process

- recipient

- culture

- $\quad$ meaning

tradition:

- $\quad$ post-semiotics, semio-pragmatics

German speaking scholars like Friedrich Krotz, Klaus Beck or Roland Burkart (in Austria) are understanding communication as a process of sense-making, based on interaction and shared meaning (Krotz, 2001; Burkart, 2002; Beck, 2006). To explain the sharing of meaning which is implemented in cultural/social contexts is nearly impossible as long as the Episteme of communication studies is re-

\footnotetext{
${ }^{25}$ Minitel is a computer generated database, which revealed French public sphere as well as private communication habits (Rincé, 1990).

${ }^{26}$ See Flichys biography on http://www.infoamerica.org/teoria/flichy $1 . h t m$ (6.5.2007). The centrality of Réseaux for French SIC has been subject of empirical research. See (based on citation analysis) Maigret (2001) as well as the DEA of Marie-Amélie Picard on Réseaux (Picard, 1995).
}

stricted to mass communication. Klaus Beck defines 'soziale Kommunikation', social communication, distinguished from technical transmission refering to Mead: 'Menschliche Kommunikation kann folglich definiert werden als wechselseitig aufeinander bezogene, reflexive und intentionale Symbolverwendung (symbolische Interaktion) mit dem Ziel gegenseitiger Verständigung über Bedeutungen (Bedeutungsvermittlung). Kommunikation ist ein voraussetzungsreicher Prozess, der auf einem von allen Kommunikationspartnern geteilten Zeichen- und Symbolrepertoire (beispielsweise einer Sprache) beruht, also kulturelle Gemeinsamkeiten und gemeinsame Erfahrungen voraussetzt' (Beck, 2006, p. 133). According to this definition, the research problem is wider than the mass communication process, in fact mass communication is only one type of social communication. $^{27}$ - Roger Blum outlines the field of interpersonal communication in communications studies in an overview (see Table 5).

All types of communication may take part in 'shared meaning' on different levels (mikro, meso, makro). ${ }^{28}$ While the German tradition highlights the field of 'Public communication' (see for the historical reasons Lacasa, 2007; and for the systematic reasons DGPuK, 2001 as well as Brosius, 2003), the French colleagues are looking at the whole scenario. This whole scenario is hardly to prove in its totality by empirical methods or could be fixed in one or few theoretical setting. This is the problem of French communication theory: It is - on a wide range - communication philosophy mixed with semiotic and/or discourse analysis. Methodologically, the two scientific communities hardly come together (see for an example in the field of audience research Albert et al., 2003).

Even the views on social communication differ in France and Germany. Firstly: the perspective 'social communication' is the dominant one in France, but the marginal one in Germany. Secondly: while few German speaking scholars refer to Symbolic Interactionism as an Episteme of communication studies, they do it mostly without fusing semiotics and pragmatics - and if they do so, only on an applied level of 'Zeichenverwendung' (the uses of signs; for example to explain speech acts, see Burkart, 2002, pp. 76-196; Krallmann \& Ziemann, 2001, pp. 13-19). In France, those two lines are bound together on a deeper epistemological level: what communication is (sui generis in human nature) is explainable in the focus of semio-pragmatism (which is not semiotics!). - Friedrich Krotz holds semiotics with their structuralist heritage for inapplicable to understand communication processes (from this standpoint he argues against Cultural Studies and their reference to French semiotics). Obviously he does not know the younger semio-pragmatist lines in France (which are in opposition to the elderly semiotics of the structuralist paradigm). In fact, Krotz (1997, p. 122) himself proposes to fuse semiotics and symbolic interactionism, too. This fusion was considered in French semiopragmatism, more than one decade before.

27 As for example Henk Prakke at University of Muenster in the 1960s was well aware of, see Kutsch (2000).

${ }^{28}$ I only mention that the model of public opinion of Jürgen Gerhards and Friedhelm Neidhardt integrates interpersonal communication with informal (encounter) and with public character (meetings, hearings...) as well as mass mediated communication (press, radio, TV) (Gerhards/Neidhardt 1990). 
Table 5. Concepts of Thinking Communication in Germany and France

\begin{tabular}{|c|c|c|}
\hline & (Mass)mediated Communication & Interpersonal Communication \\
\hline \hline $\begin{array}{c}\text { Public communication } \\
\text { press, radio, television, } \\
\begin{array}{c}\text { Non-public and/or private } \\
\text { communication }\end{array}\end{array}$ & $\begin{array}{c}\text { World wide web (for ex. websites of news- } \\
\text { papers or broadcasters) }\end{array}$ & $\begin{array}{c}\text { parlamentary debate, public discussion, lobbying, convention, hear- } \\
\text { ing, demonstration, chat... }\end{array}$ \\
\hline
\end{tabular}

What can be learned from a comparison of the corpus of ideas in French and German culture of communication studies? First of all: from an epistemological standpoint they do not exclude each other, but they could and should enrich each other (see Table $\mathbf{5}$ for the systematic side of such an enrichment). From French approaches there is to learn how to deal with epistemological questions on the nature and the social settings of communication. From the German approaches there is to learn how to operationalize concrete settings of questions about mass communication and their conditions in and consequences for society or parts of society. This does not mean that the respective counterpart is nonexistent in the other country, it only means that the two 'national ${ }^{, 29}$ research communities differ in main lines.

Looking on approaches in both countries, there is an interesting common factor: the (re)turn to the actor. But while the so called active recipient seems a bit to be considered as an isolated being in the German context (rooting in Usesand-Gratification tradition), the French researchers deal more with interdependencies between actors and structures (for example Eliséo Véron) or actors and systems (for example Alex Mucchielli). In Germany, we also find a strong impact of systems theory - but canalized through the work of Niklas Luhmann, which is a very prominent adoption in German communication studies (Meyen \& Löblich 2006, 277-296) ${ }^{31}$. If Hardt (2002) is right in his diagnosis of the defiance of a critical theory of society in German mass communication research, and Meyen \& Löblich are, too, then the Germans found the right candidate in Luhmann, who is not at all under suspicion of ideology. But with reference to Luhmann, it is almost difficult to join action and systems theory. This might be one cause that Luhmann is no reference of French SIC. In

\footnotetext{
${ }^{29}$ Science is never 'national'; but it is bound in cultural settings, especially languages. Most German researchers are not able to read French and vice versa. Nonetheless the frontiers are permeable: for ex. via the US as outlined in this article. I did not refer on the strong affiliations between French SIC and Middle and South American Communication Studies nor affiliations with some Arab countries.

30 Blum calls this scheme 'The positioning of interpersonal communication' ('Die Positionierung der interpersonalen Kommunikation'). His aim is to legitimize interpersonal communication as a field of research in communication studies. My aim is to show, that "social communication" is more than public communication.

${ }^{31}$ Meyen and Löblich estimate the influence of Luhmanns thinking on communication research in Germany for much more intense than this of his counterpart Jürgen Habermas. Habermas is widley read in French SIC - and Habermas himself had a strong input from Mead. For the Habermas reception in France see the writings of Rainer Rochlitz (among others Rochlitz, 2002).
}

France, the notion of system mostly refers to Paul Watzlawicks concept of interaction systems which are operating via 'semiosis sociale'. - In contrast Luhmann: he declares his view on communication as not compatible with communication as action nor with communication as semiosis (Luhmann, 1986, p. 203). He regards communication as a macro process of social systems (not of psychological systems!); the French approaches deal more with the interconnection of the micro and the meso level of communication in society.

When we take into account which community reads (mostly) which thinkers and (mostly) under what focus, those preferences - Watzlawick or Luhmann - are rooted in the whole field of the epistemology of communications in each of the two scientific cultures, they are not accidental.

This article has not to be taken as normative: it is not on 'better' or 'worse' communication studies but on differences between traditions, and common grounds for (re-) thinking communication theory.

\section{BIBLIOGRAPHY}

Albert, P. (2001). 'Evolution des études sur la presse. In R. Boure (Ed.), Les origines des sciences de l'information et de la communication: Regards croisés (pp. 35-41). Vielleneuve d'Ascq: Presses universitaires de Septentrion.

Albert, P., Freund, W. S., \& Koch, U. E. (Eds.). (1990). Allemagne France: Deux paysages médiatiques: Colloque franco-allemand: Frankreich - Deutschland: Medien im Vergleich. Frankfurt a. M., Bern, New York, Paris: Peter Lang.

Albert, P., Koch, U. E., Rieffel, R., Schröter, D., Viallon, P. (Eds.). (2003). Die Medien und ihr Publikum in Frankreich und Deutschland: Les médias et leur public en France et Allemagne. Paris: Editions Panthéon Assas.

Averbeck, S. (1999). Kommunikation als Prozess: Soziologische Perspektiven in der Zeitungswissenschaft. Münster, London: LIT.

Averbeck, S. (2000). Die französische Kommunikationswissenschaft, semiotische Perspektiven und die Sphären der Postmoderne. Medien \& Kommunikationswissenschaft 48(3), 396-404.

Averbeck, S. (2001). The post-1933 emigration of communication researchers from Germany: The lost works of the Weimar Generation. European Journal of Communication 16(4), 451-475.

Averbeck, S. (2002). Der Zeitungswissenschaftler Erich Everth (18781934): Eine Theorie der Öffentlichkeit und der Interessen. In S. Averbeck \& A. Kutsch (Eds.): Großbothener Vorträge zur Kommunikationswissenschaft. (Vol. 3) (pp. 9-31). Bremen: Edition Lumière.

Averbeck, S., \& Kutsch, A. (2000). Karl Jaeger - Mitteilung statt Medium: Probleme, Methoden und Gegenstände der publizistischen Wissenschaft. München: Reinhard Fischer.

Averbeck, S., \& Kutsch, A. (2002). Thesen zur Geschichte der Zeitungsund Publizistikwissenschaft 1900-1960. Medien \& Zeit 17(2-3), $67-$ 66. 
Averbeck, S., \& Kutsch, A. (Eds.). (2005). Zeitung, Werbung, Öffentlichkeit. Biographisch-systematische Studien zur Frühgeschichte der Kommunikationsforschung. Köln: Herbert von Halem.

Averbeck, S. (2005). Communication Theories in France 1975-2005: The epistemological discourse of the Sciences de l'information et de la communication. CD-ROM of the First European Communication Conference, Amsterdam 24.-26.11.2005.

http://www.uni-ipzig.de/ hsk/pgs/institut/mitarbeiter/Averbeck_publ_2005. pdf [PDF, 35 pages].

Aviso. Informationsdienst der Deutschen Gesellschaft für Publizistik- und Kommunikationswissenschaft, No. 35/2004.

Balle, F. \& Cappe de Baillon, I. (1983). Mass media research in France: An emerging discipline. Journal of communication 33(3), 146-156.

Balle, F., \& Padioleau, J.-G. (Eds.). (1972). Sociologie de l'information: Textes fondamenteaux. Paris: Librairie Larousse.

Beck, K. (2006). Kommunikation: Kommunikationsprozess. In: G. Bentele, H.-B. Brosius, O. Jarren (Eds.): Lexikon Kommunikations- und Medienwissenschaft. (pp. 126-127, 131-133). Wiesbaden: VS Verlag für Sozialwissenschaften.

Béaud, P., \& Flichy, P. (1997). Sociologie de la communication. Paris: CNET.

Béaud, P., \& Kaufmann, L. (1998). New trends in French communication research. Javnost: The Public, 1, 5-31.

Benedict, K.-U. (1986). Emil Dovifat: Ein katholischer Hochschullehrer und Publizist. Mainz: Grünewald.

Berger, Peter L., \& Luckmann, T. (1994). Die gesellschaftliche Konstruktion der Wirklichkeit: Eine Theorie der Wissenssoziologie ( $5^{\text {th }}$ ed.). Frankfurt a. M.: Fischer Taschenbuch.

Blum, R. (2000). Interpersonale Kommunikation aus der Sicht der Medienwissenschaft. Retrieved March 14, 2006 from the World Wide Web:http://visor.unibe.ch/WS01/medienthemen/Kolloquium\%20In terpersonal\%20Einfhrung.pdf

Bohrmann, H., (1986). Grenzüberschreitung? Zur Beziehung von Soziologie und Zeitungswissenschaft 1900-1960. In S. Papcke (Ed.), Ordnung und Theorie: Beiträge zur Geschichte der Soziologie in Deutschland (pp. 93-112). Darmstadt: Wissenschaftliche Buchgesellschaft.

Bohrmann, H., \& and Kutsch, A. (1975/76). Der Fall Walther Heide: Zur Vorgeschichte der Publizistikwissenschaft. Publizistik 19/20(3), 805-808.

Bohrmann, H., \& Kutsch, A. (1979). Der Beitrag 'Emigrantenpresse' im Handbuch der Zeitungswissenschaft' (1940) und sein Autor Hermann Hart. In H. Hardt, E. Hielscher, E. \& W. B. Lerg (Eds.). Presse im Exil. Beiträge zur Kommunikationsgeschichte des deutschen Exils 1933-1945 (pp. 443-437). München, New York: K. G. Saur.

Bohrmann, H., \& Kutsch, A. (1979a). Pressegeschichte und Pressetheorie: Erich Everth (1878-1934). Publizistik 24(3), 386-403.

Boure, R. (1997). Les sciences de l'information et de la communication et de la communication au risque de l'expertise? Sur et sous des pratiques scientifiques. Réseaux 14(82/83), 233-254.

Boure, R. (Ed.). (2002). Les origines des sciences de l'information et de la communication: Regards croisés. Villeneuve d'Ascq: Presses universitaires de Septentrion.

Boure, Robert (2005). Réflexions d'institutionnalisation des disciplines: Sciences de l'information et de la communication versus l'économie? Communication (Québec) 24(1), 9-36.

Brosius, H.-B. (2003). Kommunikationswissenschaft als empirischnormative Sozialwissenschaft. In H. Richter \& W.-H. Schmitz (Eds.): Kommunikation - ein Schlüsselbegriff der Humanwissenschaften? (pp. 401-415). Münster: Nodus Publikationen.

Burkart, R. (2002). Kommunikationswissenschaft: Grundlagen und Problemfelder: Umrisse einer interdisziplinären Sozialwissenschaft $\left(4^{\text {th }}\right.$, revised ed.). Wien: Böhlau (UTB).

Carey, J. W. (1992). Communication as culture: Essays on media and society. New York, London: Routledge [first1989].

Cazeneuve, J. (1982). La France. Les cahiers de la communication 2(4/5), 369-384.

Charaudeau, P. (2006). Un modèle socio-communicationnel du discours (entre situation de communication et stratégies d'individuation). In C. Dessignes \& J.-P. Esquenazi (Eds.), Discours - outils de communication - pratiques: quelle(s) pratmatique(s)? En hommage à Daniel Bougnoux (pp. 15-40). Paris: L'Harmattan.

Clark, Terry N.[ichols] (1974). Die Stadien wissenschaftlicher Institutionalisierung. In P. Weingart (Ed.), Wissenschaftssoziologie II: Determinanten wissenschaftlicher Entwicklung (pp. 105-121). Frankfurt a. M.: Athenäum Fischer 1974. le Coadic, Y. (2006). Qu'est-ce qui fait sciences da la science de l'information? Retrieved June 1, 2006 from the World Wide Web: http://ccsd.cnrs./fr/sic_00067969 [PDF, 10 pages].

Comité national d'évaluation (CNE). (1993). Les sciences de l'information et de la communication: Rapport d'Evaluation. Paris: CNE.

Couzinet, V. (2001). Jean Meyriat, théoricien et praticien de l'informationdocumentation. Paris: ADBS.

Debatin, B. (2002). Paul Watzlawick/Janet H. Beavin/Don D. Jackson: Pragmatics of human communication. A study of interactional patterns, pathologies, and paradoxes. In A. Kutsch \& C. Holtz-Bacha (Eds.), Schlüsselwerke für die Kommunikationswissenschaft (pp. 434-436). Wiesbaden: Westdeutscher Verlag.

Delporte, C. (1999). Les journalistes en France 1880-1950: Naissance et construction d'une profession. Paris: Seuil.

Devèze, J. (2001). Quelques éléments de la genèse des sciences de l'information et de la communication en France. In D. Georgakakis \& J.-M. Utard (Eds.), Science des médias: Jalons pour une histoire politique (pp. 112-121). Paris: L'Harmattan.

Donsbach, W.; Laub, T.; et al. (2005). Anpassungsprobleme in der Kommunikationswissenschaft: Themen und Herkunft der Forschung in den Fachzeitschriften ,Publizistik' und ,Medien \& Kommunikationswissenschaft'. Medien \& Kommunikationswissenschaft 53(1), 46-72.

Duchkowitsch, W. \& Hausjell, F. (1993). 1942-1992: Ein halbes Jahrhundert Institut für Publizistik- und Kommunikationswissenschaft an der Universität Wien. Publizistik 37(2), 228-230.

Escarpit, R. (1992). Interview de Robert Escarpit en 1992 par Jean Devèze and Anne-Marie Laulan. Retrieved September 19, 2003 from the World Wide Web: http://www.cetecinfo.org/jlmichel/Textes.Escarpit.92.html [PDF, 13 pages].

Fabris, H.-H. (1983). Österreichs Beitrag zur Kommunikationswissenschaft und Forschung: Zwischen Aufbruch und Verhinderung. Publizistik 27(2), 204-218.

Galtung, J. (1983). Struktur, Kultur und intellektueller Stil: Ein vergleichender Essay über sachsonische, teutonische, gallische und nipponische Wissenschaft. Leviathan: Zeitschrift für Sozialwissenschaft 11(3), 303-339.

Georgakakis, D. \& Utard, J.-M. (Eds.). (2001). Science des médias: Jalons pour une histoire politique. Paris: L'Harmattan.

Gerhards, J. \& Neidhardt, F. (1992). Strukturen und Funktionen von Öffentlichkeit. Berlin: WZB.

Göppner, S. (2005). Die Zeitungswissenschaft an der Universität Zürich bis 1945: Institutionalisierung und theoretische Ansätze. In Schade, Edzard (Ed.), Publizistikwissenschaft und öffentliche Kommunikation (pp. 47-69). Konstanz: UVK.

Gritti, J. (1999). Les années Cinquante dans les recherches en communication. Recherches en communication, 11, 21-42.

Große, A. (1989). Wilhelm Kapp und die Zeitungswissenschaft: Geschichte des Instituts für Publizistik- und Zeitungswissenschaft an der Universität Freiburg i.Br. Münster, New York: Waxmann.

Groth, O. (1948). Die Geschichte der deutschen Zeitungswissenschaft: Probleme und Methoden. München: Weinmayer.

Hachmeister, L. (1984). Theoretische Publizistik: Studien zur Geschichte der Kommunikationswissenschaft in Deutschland. Berlin: Spiess 1987.

Hammami, S. (2005). Les Sciences de l'information et de la communication dans le monde arabe: Réflexions sur les difficultés d'émergence d'une discipline. Revue Tuniesienne de communication 45(1): 7-42.

Hardt, H. (2002). Am Vergessen Scheitern: Essay zur historischen Identität der Publizistikwissenschaft. Medien \& Zeit (Wien) 17(2/3), 34-39.

Hausjell, F., Duchkowitsch, W. \& Semrad, B. (2004): Die Spirale des Schweigens: Zum Umgang mit der nationalsozialistischen Zeitungwissenschaft. Münster, London: LIT.

Hemels, J., Kutsch, A., \& Schmolke, M. (Eds.) (2000). Entgrenzungen: Erinnerungen an Henk Prakke. Assen: Van Gorcum.

Hepp, A. (2004). Cultural Studies und Medienanalyse: Eine Einführung ( $^{\text {nd }}$ ed.). Wiesbaden: VS Verlag für Sozialwissenschaften.

Heuser, J. (1994). Zeitungswissenschaft als Standespolitik: Martin Mohr und das ,Deutsche Institut für Zeitungskunde' in Berlin. Hamburg, Münster: LIT.

Holtz-Bacha, C. \& Kutsch, A. (2002). Schlüsselwerke für die Kommunikationswissenschaft. Wiesbaden: Westdeutscher Verlag.

Hopfe, A. (2007). Kommunikationsnetzwerke und Unternehmenskultur: Positionen, Diskussionen und Ergebnisse der französischen Kommunikationswissenschaft zur internen Unternehmenskommunikation. Magister Thesis, Martin-Luther-Universität Halle-Wittenberg. 
Jarren, O. (2000). Aufbruch und Umbruch: Situationen und Perspektiven der Publizistik- und Kommunikationswissenschaft in der Schweiz. Medien Journal (Innsbruck) 24(2), 10-18.

Jeanneret, Y. (2001). Les sciences de l'information et de la communication: Une discipline méconnue en charge d'enjeux cruciaux. La lettre d'inforcom, 23(60), 3-45.

Jeanneret, Y. \& Ollivier, B. (Eds.). (2004). Les sciences de l'information et de la communication: Savoirs et pouvoirs. Paris: CNRS Editions.

Jones, D. (2001). Medien- und Kommunikationsforschung in Spanien: Ein Überblick. Medien \& Kommunikationswissenschaft 49(4), 528-545.

Jouet, J. (2000). Retour critique sur la sociologie des usages. Réseaux, 18(100), 488-521.

Käsler, D. (1984). Die frühe deutsche Soziologie und ihre Entstehungsmilieus: Eine wissenschaftssoziologische Untersuchung. Opladen: Westdeutscher Verlag.

Katz, E. (1987). Communication Research since Lazarsfeld. Public Opinion Quarterly 51(4), 25-45.

Kim, S.-J. \& Westerbarkey, J. (1998). Kommunikationswissenschaft in Korea: Geschichte, Schwerpunkte und aktuelle Situation. Publizistik 43(2), 158-171.

Klein, P. (2005): Die Anfänge der Kommunikationsforschung in den Niederlanden. In S. Averbeck, A. Kutsch \& S. Voigt (Eds.), Großbothener Vorträge zur Kommunikationswissenschaft (pp. 97-120). Vol. 6. Bremen: Edition Lumière.

Klein, P. (2006). Henk Prakke und die funktionale Publizistik: Über die Entgrenzung der Publizistik- zur Kommunikationswissenschaft. Münster: LIT.

Klose, H.-G. (1989). Zeitungswissenschaft in Köln: Ein Beitrag zur Professionalisierung der deutschen Zeitungswissenschaft in der ersten Hälfte des 20. Jahrhunderts. München, New York, London: K.G. Saur.

Koenen, E. (2005). Ein 'einsamer' Wissenschaftler? Erich Everth und das Leipziger Institut für Zeitungskunde zwischen 1926 und 1933: Ein Beitrag zur Bedeutung des Biographischen für die Geschichte der Zeitungswissenschaft. Medien \& Zeit 20(1), 38-50.

Koenen, E. (2007): Fachgeschichte im Generationenfokus: Überlegungen zum Begriff der Generation als fachhistorischer Kategorie am Beispiel der Geschichte der Kommunikationswissenschaft. In Deutsche Gesellschaft für Soziologie (Ed.). Die Natur der Gesellschaft. 33. Kongress der DGS, 9.-13. Oktober 2006. Universität Kassel [forthcoming].

Koenen, E. (2007a). Auf Schleichwegen in die neue Zeit? Anmerkungen zur Identitätssuche und Opportunitätsstrukur ehemaliger NS'Führungswissenschaften' am Beispiel des 'Überlebens' der Zeitungswissenschaft nach 1945. In Deutsche Gesellschaft für Soziologie (Ed.), Die Natur der Gesellschaft. 33. Kongress der DGS, 9.-13. Oktober 2006 Universität Kassel [forthcoming].

Koivisto, J. \& Thomas, P. (2007). Mapping Media and Communication Research: Germany. Helsinki: University of Helsinki. Retrieved July 14, 2007 from the World Wide Web: http://www.valt.helsinki.fi/blogs/crc/ReportGermany.pdf

Kopper, G. (2004). Review of the book Kommunikation, Medien, Gesellschaft: Eine Bestandsaufnahme deutscher und französischer Wissenschaftler. Publizistik 49(1): 102-104.

Krallmann, D. \& Ziemann, A. (2001). Grundkurs Kommunikationswissenschaft. München: Wilhelm Fink.

Krotz, F. (1997). Gesellschaftliches Subjekt und kommunikative Identität: Zum Menschenbild der Cultural Studies. In pp. 117-125 in A. Hepp \& R. Winter (Eds.), Kultur - Medien - Macht: Cultural Studies und Medienanalyse (pp. 117-125). Opladen: Westdeutscher Verlag.

Krotz, F. (2001). Der symbolische Interaktionismus und die Kommunikationsforschung: Zum hoffnungsvollen Stand einer schwierigen Beziehung. In P. Rössler, U. Hasebrink \& M. Jäckel (Eds.), Theoretische Perspektiven der Kommunikationsforschung (pp. 73-96). München: Reinhard Fischer.

Kuhn, T. S. (1976). Die Struktur wissenschaftlicher Revolutionen. Frankfurt a. M.: Suhrkamp [first The structure of scientific revolutions. University of Chicago Press 1962].

Kutsch, A. (Ed.) (1984). Zeitungswissenschaft im Dritten Reich: Sieben biographische Studien. Köln: Ertay Hayit.

Kutsch, A. (1985). Rundfunkwissenschaft im Dritten Reich: Geschichte des Instituts für Rundfunkwissenschaft an der Universität Freiburg. München, New York, London, Paris: K. G. Saur.

Kutsch, A. (1988). Die Emigration der deutschen Zeitungswissenschaft ab 1933: Anmerkungen zu einem vergessenen Thema. Medien \& Zeit 3(1), 3-16.
Kutsch A. (2000). Die Öffnung der publizistikwissenschaftlichen Perspektive. In J. Hemels, A. Kutsch \& M. Schmolke (Eds.), Entgrenzungen: Erinnerungen an Henk Prakke (pp. 27-42). Assen: van Gorcum.

Kutsch, A. (2006). Verdrängte Vergangenheit: Darstellungstechniken und Deutungen der Fachgeschichte im 'Dritten Reich' in den Personalien der Publizistik. In C. Holtz-Bacha, A. Kutsch, W. Langenbucher, K. Schönbach (Eds.), 50 Jahre Publizistik (pp. 73-112). Wiesbaden: VS Verlag für Sozialwissenschaften.

Kutsch, A. \& Pöttker, H. (Eds.). (1997). Zeitungswissenschaft autobiographisch: Zur Entwicklung einer Wissenschaft in Deutschland. Opladen: Westdeutscher Verlag.

Lacasa, I. (2007). Entre ciencia y praxis: La Zeitungswissenschaft durante la República de Weimar: Los conceptos de 'öffentliche Meinung' und ,Öffentlichkeit'. PhD Dissertation, Universitat Autònoma de Barcelona.

La lettre d'inforcom. Bulletin de la Société des Sciences de l'information et de la communication, No. 1/1975-No. 25/1987 (Supplément à MSH informations). Paris: SFSIC/MSH.

La lettre d'inforcom. Bulletin de la Société des Sciences de l'information et de la communication, No. 36/1990-No. 61/2002. Retrieved May 17, 2007 from the World Wide Web: http://www.sfsic.org/sicnet/ publications/4-lettre.htm [incomplete].

Latour, B. \& Woolgar, S. (1979). Laboratory Live: The social construction of scientific facts. Beverly Hills: Sage.

Lazar, J. (1991). Sociologie de la communication de masse. Paris: Armand Colin.

Lazar, J. (1992). La Science de la communication. Paris: PUF.

Lepenies, W. (Ed.). (1981). Geschichte der Soziologie: Studien zur kognitiven, sozialen und historischen Identität einer Disziplin. (Bd. 4). Frankfurt a. Main: Suhrkamp.

Lepenies, W. (1988). Die drei Kulturen: Soziologie zwischen Literatur und Wissenschaft (2nd ed.). Hamburg: Rowohlt [first 1985].

Lepenies, W. (1989). Gefährliche Wahlverwandtschaften: Einige Etappen in den Beziehungen deutscher und französischer Sozialwissenschaftler. In W. Lepenies, Gefährliche Wahlverwandtschaften: Essays zur Wissenschaftsgeschichte (pp. 80-110). Stuttgart: Philipp Reclam jr.

Linde, I. (2005). 'La médiologie' von Régis Debray: Rezeption und Relevanz in der deutschsprachigen Medientheorie. Magister Thesis, University of Leipzig.

Löblich, M. (2004). Das Menschenbild in der Kommunikationswissenschaft: Otto B. Roegele. Münster, London: LIT

Löblich, M. (2007). German Publizistikwissenschaft and its shift from a humanistic to an empirical social scientific discipline: Elisabeth Noelle-Neumann, Emil Dovifat and the Publizistik Debate. European Journal of Communication 22(1), 69-88.

Löblich, M. (2007a). Verwissenschaftlichte Medienpolitik und der Wandel der Publizistikwissenschaft zur empirischen Sozialwissenschaft. Contribution to the conference of the Deutsche Gesellschaft für Publizistik- und Kommunikationswissenschaft (DGPuK), 16.-18. Mai 2007 in Bamberg.

Luhmann, N. (1986). Soziale Systeme. Frankfurt a. M.: Suhrkamp.

Maigret, E. (2001). La communication en revues. L'enquete sur les revues menée par le ministère de la recherche. Hermès, No. 30, 7-11.

Maigret, E. (2004). Sociologie et communication: Vielles lunes disciplinaires et idées neuves. In Y. Jeanneret \& B. Ollivier (Eds.), Les sciences de l'information et de la communication, savoirs et pouvoirs (pp. 111-113). Paris: CNRS éditions.

Marhuenda, J.-P. (1983). A propos de quelques bilans de la recherche française en communication. Les cahiers de la communication 3(5), 427-448.

Massmann, A. (2004). Von 'Kommunikation für Entwicklung' zur 'cultura mediática’. Publizistik, 49(3), 275-291.

Mattelart, A. (1983). Technology, Culture and Communication: Research and policy priorities in France. Journal of Communication 33(3), 59-73.

Mattelart, A. \& Mattelart, M. (2002). Histoire des théories de la communication $\left(3^{\text {rd }}\right.$, revised ed.). Paris: La Découverte [first 1995].

Mattelart, A. \& Neveu, E. (2003). Introduction aux Cultural Studies. Paris: La Decouverte.

Mead, G. H. (1975). Geist, Identität und Gesellschaft ( $2^{\text {nd }}$ edition). Frankfurt a.M.: Suhrkamp [first Mind, self and society: From the standpoint of a social behaviourist. University of Chicago Press 1934].

Mercier, A. (1994). Institutionnalisation de la profession de journaliste. Hermès, No. 13-14, 219-235. 
Meyen, M. (2007). Geschichte der Kommunikationswissenschaft als Generationengeschichte: Über den Einfluß prägender Lebenserfahrungen der zentralen Akteure auf die Entwicklung einer akademischen Disziplin im deutschsprachigen Raum. Studies in Communication Sciences 7(1), 9-36.

Meyen, M. \& Löblich, M. (2004). 80 Jahre Zeitungs- und Kommunikationswissenschaft in München: Bausteine zu einer Institutsgeschichte. Köln: Herbert von Halem.

Meyen, M. \& Löblich, M. (2006). Klassiker der Kommunikationswissenschaft. Konstanz: UVK.

Meyriat, J. (1994). Interview de Jean Meyriat, Président d'honneur de la SFSIC. Entretien avec Jean Devèze. Retrieved September 19, 2003 from the World Wide Web: http://www.cetecinfo.org/jlmichel/Textes.Meyriat.html

Meyriat, J. \& Miège, B. (2002). Le projet des SIC: de l'émergent à l'irréversible (fin des années 1960-milieu des années 1980). In R. Boure (Ed.), Les origines des sciences de l'information et de la communication: Regards croisés (pp. 45-70). Paris: Presses Universitaires de Septentrion.

Miège, B. (1995). La pensée communicationnelle. Paris: Presses universitaires de Grenoble.

Monschein, W. \& Randl, F. (1996). 50 Jahre Kommunikationswissenschaft an der Universität Wien (1942-1992). Medien \& Zeit 11(1), 4-21 and 11(2), 14-40.

Morin, E. (1972). Nouveaux courants dans l'étude des communications de masse: Rapport UNESCO. In F. Balle \& J.-G. Padioleau (Eds.), Sociologie de l'information: Textes fondamenteaux (pp. 97-118). Paris: Librairie Larousse.

Mucchielli, A. (2004). La nouvelle communication. Paris: Armand Colin.

Olivesi, Stéphane (Ed.). (2006). Sciences de l'information et de la communication: Objets, savoirs, discipline. Grenoble: PUG.

Palermiti, R. \& Polity, Y. (2002). Dynamiques de l'institutionalisation sociale et cognitive des sciences de l'information. In R. Boure (Ed.), Les origines des sciences de l'information et de la communication (pp. 95-123). Villeneuve d'Asq: Septentrion.

Perret, J.-B. (2004). Y a-t-il des objets plus communicationnels que d'autres? In Y. Jeanneret \& B. Ollivier (Eds.), Les sciences de l'information et de la communication: Savoirs et pouvoirs (pp. 121128). Paris: CNRS.

Picard, M.-A. (1995). Réseaux: Etude d'une revue de sciences sociales. DEA-Thesis, Sorbonne, Paris

Pollak, M. (1990). Lazarsfelds Einfluss auf die internationale Verbreitung der empirischen Sozialforschung: Kontinuität und/oder Wandel eines wissenschaftlichen Projektes. In W.-R. Langenbucher (Ed.), Paul F. Lazarsfeld: Die Wiener Tradition der empirischen Sozial und Kommunikationsforschung (pp. 131-147). München: Ölschläger 1990.

Puustinen, L. (2007). Mapping Media and Communication Resarch: France. Helsinki: University of Helsinki, Finland. Retrieved July 14, 2007 from the World Wide Web: http://www.valt.helsinki.fi/blogs/crc/ReportFrance.pdf [101 pages].

Reimann, H. (1990). Paul Lazarsfeld und die Entstehung der Massenkommunikationsforschung als Verbindung amerikanischer und europäischer Forschungstraditionen. In W.-R. Langenbucher (Ed.), Paul F. Lazarsfeld: Die Wiener Tradition der empirischen Sozialund Kommunikationsforschung (pp. 112-130). München: Ölschläger.

Revel, J., \& Wachtel, N. (Eds.). (1996). Une école pour les sciences sociales: De la VI ieme section à l'Ecole des Hautes Etudes en Sciences sociales. Paris: CERF/Editions de EHESS.

Rieffel, R. (2001). Sociologie des médias. Paris: Ellipses.

Rincé, J.-Y. (1990). Le Minitel. Paris: PUF.

Robine, N. (2001). Hommage à Robert Escarpit: Universitaire, écrivain, journaliste 1918-2000: Suivi d'une bibliographie des ouvres de Robert Escarpit par Maika Forgeaud/Nicole Robine. Bordeaux: Presses universitaires de Bordeaux.

Rochlitz, R. (Ed.). (2002). Habermas: L'usages public de la raison. Paris: PUF.

Roegele, O. B., \& vom Bruch, R. (1986). Von der Zeitungskunde zur Publizistik: Biographisch-institutionelle Stationen der deutschen Zeitungswissenschaft in der ersten Hälfte des 20. Jahrhunderts. Frankfurt a.M: Haag + Herchen.
Ruellan, D. (1997). Le professionalisme du flou: Identité et savoir faire des journalistes français. Grenoble: PUG.

Saxer, U. (1993). Basistheorien und Theorienbasis in der Kommunikationswissenschaft: Theorienchaos oder Chaostheorie? In G. Bentele \& M. Rühl (Eds.), Theorien öffentlicher Kommunikation (pp. 175187). München: Ölschläger.

Saxer, U. (2000). Mythos Postmoderne: Kommunikationswissenschaftliche Bedenken. Medien \& Kommunikationswissenschaft 48(2), 85-92.

Schade, E. (Ed.). (2005). Publizistikwissenschaft und öffentliche Kommunikation: Beiträge zur Reflexion der Fachgeschichte. Konstanz: UVK.

Schäfer, F. (2005). Ono Hideo und der Ursprung der Zeitungswissenschaft (Shinbungaku) in Japan. In S. Averbeck \& A. Kutsch (Eds.), Zeitung, Werbung, Öffentlichkeit: Biographisch-systematische Studien zur Frühgeschichte der Kommunikationsforschung (pp. 23-54). Köln: Herbert von Halem.

Schanze, H. (Ed.). (2002). Metzler Lexikon Medienwissenschaft - Medientheorien. Ansätze, Personen, Grundbegriffe. Stuttgart, Weimar: Metzler.

Schwer, K. (2005). 'Typisch deutsch'? Zur zögerlichen Debatte der Cultural Studies in der deutschen Kommunikationswissenschaft. Münchner Beiträge zur Kommunikationswissenschaft, No. 2 [Elektronische Publikationen der Universität München]. Retrieved June 1, 2007 from the World Wide Web: http://epub.ub.uni-muenchen.de/ archive/00000521 [PDF, 17p.].

Sösemann, B. (Ed.). (1998). Emil Dovifat: Studien zu Leben und Werk. Berlin: Walter de Gruyter.

Sösemann, B. (Ed.). (2001). Fritz Eberhard: Rückblende auf Biographie und Werk. Stuttgart: Franz Steiner.

Souchon, M. (2004). Du CECMAS à France Télévision, un itinéraire: Propos recueillis par Isabelle Veyrat-Masson. Médias \& Sociétés 2(3), 195-205.

Straetz, S. (1984). Hans A. Münster (1901 - 1963): Sein Beitrag zur Entwicklung der Rezipientenforschung. Frankfurt a. M.: Haag und Herchen.

Süss, D. (2000). Institutionelle Strukturen und Ausbildungssituation: Kommunikations- und Medienwissenschaft in der Schweiz. Medien Journal 24(2), 19-27.

Szyszka, P. (1990). Zeitungswissenschaft in Nürnberg (1919 - 1945): ein Hochschulinstitut zwischen Praxis und Wissenschaft. Nürnberg: Verlag der kommunikationswiss. Forschungsvereinigung.

Tétu, J.-F. (2002). Sur les origines littéraires des sciences de l'information et de la communication. In R. Boure (Ed.), Les origines des sciences de l'information et de la communication: Regards croisés (pp. 7190). Villeneuve d'Asqc: Presses universitaires de Septentrion.

Traub, H. (1933). Grundbegriffe des Zeitungswesens. Stuttgart: C. E. Poeschel.

Véron, E. (1981). Construire l'évènement: Les médias et l'accident de tree mile island. Paris: Editions du Minuit.

Véron, E. (1987). La sémiosis sociale: Fragments d'une théorie de la discursivité. Paris: Université de Vincennes.

Véron, E. (1988). Entre Peirce et Bateson: une certaine idée du sens. In Y. Winkin (Ed.): Bateson - premier état d'un héritage (pp. 171-183). Colloque de Cérisy. Paris: Editions du Seuil.

Véron, E. (2004). Fragmentos de un tejido. Barcelona: Editoria Gedisa, S.A.

Vroons, E. (2005). Communication Studies in Europe: A sketch of the situation around 1955. Gazette 67(6), 495-522.

Weingart, P. (1976). Wissensproduktion und soziale Struktur. Frankfurt a M.: Suhrkamp.

Wilke, J. (1991). Cinematography as a medium of communication: The promotion of research by the League of Nations and the role of Rudolf Arnheim. European Journal of Communication 6(3), 337 353.

Wilke, J. (Ed.). (2005). Die Aktualität der Anfänge: 40 Jahre Publizistikwissenschaft an der Johannes-Gutenberg-Universität Mainz. Köln Herbert von Halem.

Wilke, J. (2006). Von der 'entstehenden' zur 'etablierten' Wissenschaft: Die institutionelle Entwicklung der Kommunikationswissenschaft als universitäre Disziplin. In C. Holtz-Bacha, A. Kutsch, W. Langenbucher, K. Schönbach (Eds.), 50 Jahre Publizistik (pp. 317-338). Wiesbaden: VS Verlag für Sozialwissenschaften. 